\title{
Factors associated with leisure activities of elderly residents in rural areas
}

\author{
Fatores associados às atividades de lazer de idosos residentes na zona rural
}

Factores relacionados a las actividades recreativas de ancianos residentes en la zona rural

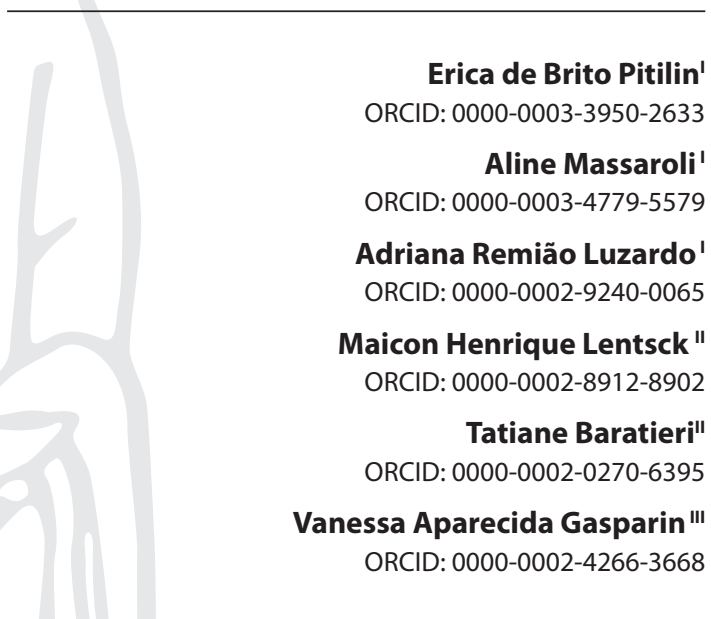

'Universidade Federal da Fronteira Sul. Chapecó, Santa Catarina, Brazil. "Universidade Estadual do Centro-Oeste. Guarapuava, Paraná, Brazil.

"I Universidade do Estado de Santa Catarina. Chapecó, Santa Catarina, Brazil.

How to cite this article:

Pitilin EB, Massaroli A, Luzardo AR, Lentsck MH, Baratieri T, Gasparin VA. Factors associated with leisure activities of elderly residents in rural areas.

Rev Bras Enferm. 2020;73(Suppl 3):e20190600. doi: http://dx.doi.org/10.1590/0034-7167-2019-0600

\section{Corresponding author: Erica de Brito Pitilin E-mail: erica.pitilin@gmail.com}

EDITOR IN CHIEF: ANTONIO JOSÉ DE ALMEIDA FILHO ASSOCIATE EDITOR: ALEXANDRE BALSANELLI

\section{ABSTRACT}

Objective: To identify factors associated with leisure activities of elderly residents in rural areas. Method: Quantitative cross-sectional study carried out with 258 elderly living in the rural area of Paraná. The collection instrument addressed sociodemographic, economic, and self-reported leisure activities. The association between variables and leisure activities was verified by means of bivariate and multivariate analysis. Results: Among the elderly interviewed, $63.9 \%$ were female, and $36.1 \%$ were male, with an average of 68.3 years old ( \pm 5.8 years). Participation in leisure activities was high $(79.8 \%)$, and the factors associated with their practice were: marital status, gender, and education. Conclusion: Considering that the practice of leisure activities promotes better living and health conditions, we reinforce the need to implement actions and instruments that provide individual and collective leisure in rural areas.

Descriptors: Aged; Health Services for the Elderly; Rural Communities; Leisure Activities; Rural Population.

\section{RESUMO}

Objetivo: Identificar os fatores associados às atividades de lazer de idosos residentes na zona rural. Método: Estudo transversal quantitativo realizado com 258 idosos residentes na área rural do Paraná. O instrumento para a coleta abordou questões sociodemográficas, econômicas e atividades de lazer autorreferidas. A associação entre as variáveis e as atividades de lazer foi verificada por meio de análise bivariada e multivariada. Resultados: Entre os idosos entrevistados, $63,9 \%$ eram do sexo feminino e $36,1 \%$ do sexo masculino, com média de idade de 68,3 anos ( $\pm 5,8$ anos). A participação em atividades de lazer foi alta $(79,8 \%)$, e os fatores que se associaram à sua prática foram: situação conjugal, sexo e escolaridade. Conclusão: Considerando que a prática de atividades de lazer promove melhores condições de vida e saúde, reforça-se a necessidade de implementação de ações e instrumentos que proporcionem lazer individual e coletivo no espaço rural.

Descritores: Idoso; Saúde do Idoso; Zona Rural; Atividades de Lazer; População Rural.

\section{RESUMEN}

Objetivo: Identificar los factores relacionados a las actividades recreativas de ancianos residentes en la zona rural. Método: Estudio transversal cuantitativo realizado con 258 ancianos residentes en el área rural de Paraná. El instrumento para la recogida abordó cuestiones sociodemográficas, económicas y actividades recreativas autoreferidas. La relación entre las variables y las actividades recreativas ha sido verificada por medio de análisis bivariado y multivariado. Resultados: Entre los ancianos entrevistados, 63,9\% fueron del sexo femenino y $36,1 \%$ del sexo masculino, con media de edad de 68,3 años ( \pm 5,8 años). La participación en actividades recreativas ha sido alta (79,8\%), y los factores que se asociaron a su práctica han sido: situación conyugal, sexo y escolaridad. Conclusión: Considerando que la práctica de actividades recreativas promueve mejores condiciones de vida y salud, se refuerza la necesidad de implementación de acciones e instrumentos que proporcionen ocio individual y colectivo en el espacio rural.

Descriptores: Anciano; Salud del Anciano; Medio Rural; Actividades Recreativas; Población Rural. 
Factors associated with leisure activities of elderly residents in rural areas Pitilin EB, Massaroli A, Luzardo AR, Lentsck MH, Baratieri T, Gasparin VA.

\section{INTRODUCTION}

Despite being a natural process, population aging does not occur homogeneously for all individuals; it is associated with the conditions of life and health experienced. Events of a physiological, pathological, psychological, social, cultural, environmental, and economic nature significantly influence the quality of life of the elderly and in a particular way depending on the environment in which they live - urban or rural ${ }^{(1)}$.

It is believed that in rural areas, there is a natural potential for the elderly's vulnerability due to difficulties in accessing means of communication, transportation, leisure, and health services, due to the scarcity in these locations and the distance to travel to urban areas $^{(2-3)}$.

According to the Organic Law of Health, in addition to access to essential goods and services, other determinants influence the health levels of the population, including access to leisure ${ }^{(4)}$, which represents an increasingly researched and constitutes a basic human need and social right ${ }^{(5)}$. Although there is no consensus in the literature on the definition of leisure, it is increasingly incorporated into different instances and knowledge, including the health field.

In this study, leisure comprises a set of occupations to which the individual can freely indulge, whether for rest, fun, recreation, or entertainment. Besides, it is a favorable moment to develop training or information in an unconcerned way, voluntary social participation, or free creative capacity, after freeing of professional, family, and social obligations ${ }^{(6)}$.

Contemporary society has been challenged to respond to the demands of science and technology that mainly affect the increase in longevity, which ends up requiring public policies and social programs aimed at the quality of life, including leisure for the elderly. Several studies relate to time and leisure activities to well-being in the biological and social context of the elderly ${ }^{(7-8)}$. However, little research focuses on the issue of leisure development in rural areas.

In this sense, knowing leisure activities constitutes a privileged target for study, allowing a greater understanding of the social processes involved when carrying out these activities, enabling forms of intervention that promote more positive attitudes to people and increase levels of individual well-being and social ${ }^{(9)}$.

Also, studies that treat free time as an opportunity for healthy personal development can facilitate the planning of leisure activities, both preventive and therapeutic ${ }^{(10)}$.

Considering the aspects mentioned above - mainly because the elderly constitute $14.3 \%$ of the Brazilian population, with the South region having the highest percentage of this population ${ }^{(11)}$, and that leisure is inserted in the context of health promotion -, identifying leisure-promoting activities can help to organize targeted actions to assist this public. Also, the increase in life expectancy and the scarcity of studies carried out with the rural elderly population prompted this research.

\section{OBJECTIVE}

To identify factors associated with leisure activities of elderly residents in the rural area.l

\section{METHODS}

\section{Ethical aspects}

The study followed the ethical precepts as recommended by the National Health Council, being approved by the Research Ethics Committee of the State University of Maringá.

\section{Study Design, location, and period}

A quantitative cross-sectional study. The instrument selected to guide the methodology was the Strengthening the Reporting of Observational Studies in Epidemiology (STROBE).

The study was carried out with the elderly population living in the rural area of the municipality of Prudentópolis (PR) and registered in Programa de Atenção Integral à Saúde do Idoso ( PAISI-Program for Comprehensive Health Care for the Elderly). The municipality is the second-largest in size in the state and the only one considered as predominantly rural, with $53.96 \%$ of its population residing in this area. It comprises an estimated population of 51,281 inhabitants, totaling 5,782 over the age of 60 , of which 1,842 (32.2\%) live in the urban area, while 3,940 (69.4\%) in the rural area ${ }^{(12)}$.

In the municipality under study, there are 169 locations in the rural area, distributed along with its territorial extension, of which 63 are the most populous. Unidades Básicas de Saúde (UBS - Basic Health Units) cover only 14 of these.

The researchers themselves collected the data in November 2016, with the support of the local management, who offered physical space in a private room in the rural UBS.

\section{Sample and inclusion criteria}

The elderly who participate in the study met the inclusion criteria: being 60 years or older ${ }^{(13)}$, registered in the program, and able to answer the study questions from obtaining the minimum score of 20 points of the Mini-Mental State Examination (MMSE) test. This screening instrument allows the global assessment of the patient's mental state, using 11 simple tasks to assess orientation to time, orientation to place, attention, language, and praxis, enabling the assessment of presence or absence of the cognitive capacity necessary to respond to the study ${ }^{(14)}$.

The sample size was calculated from the total number of elderly attended and registered by the program $(n=802)$, with an estimated error of $5 \%$ and $95 \%$ reliability, plus $20 \%$ for possible losses. Through proportional stratification, 270 elderly were selected; of these, eight refused to participate, and four did not reach the minimum score listed by the MMSE, resulting in 258 participants.

\section{Study Protocol}

The selection of participants took place through the use of the systematic approach in the waiting list for assistance, together with health professionals working at PAISI. It started by inviting the last user on the waiting list; if there was a refusal, the invitation was made immediately to the previous one and so on. Each interview lasted an average of 20 minutes.

The instrument for the collection was a semi-structured questionnaire with questions that addressed sociodemographic information 
such as age, gender, marital status, education, in addition to economic factors such as income. Each participant selfreported leisure activities according to their wishes, besides the duration and frequency of these activities.

Such activities were classified into: physical, which included gymnastics, walking, stretching and dancing; crafts/ arts, such as gardening, handicrafts, embroidery, fishing, and cultural presentations; intellectual, linked to reading, television and radio; social, referring to conversations, games (cards, dominoes, bocce, bingo); and tourism, associated with trips (visiting grandchildren) carried out with religious entities ${ }^{(6)}$.

\section{Results analysis and statistics}

The collected data were tabulated and evaluated by pairs to correct any typing errors and then analyzed using the statistical software Statistical Package for the Social Sciences (SPSS), version 20.0.

All aspects were defined as independent variables concerning the outcome of the study (leisure activity), separately.

The statistical calculation performed to test the association between independent variables, and leisure activity was the bivariate analysis at each level of determination. Pearson's chi-square and Fisher's exact tests were also used for gender differences. We used the odds ratio for the association between the variables. Outliers were excluded, and the multicollinearity test evaluation occurred according to the parameters of Tolerance and VIF (Variance Inflation Factors).

The variables that were statistically significant in the bivariate analysis $(p<0.20)$ were selected for multivariate analysis by using the unconditional method forward stepwise (likelihood ratio).

For all inferential statistical tests, significance level $p$ $<0.05$ and Nagelkerke R values ${ }^{2}$ were used. The HosmerLemeshow test assessed the goodness of fit. The Kolmogorov-Smirnov test was used to verify the normality of the numerical data.

\section{RESULTS}

The study pointed out that, of the 258 elderly investigated, $63.9 \%$ (165) were female and $36.1 \%$ (93) male, with an average age of 68.3 years old $( \pm 5.8$ years). The participation of the elderly in the rural area in leisure activities was $79.8 \%$ ( $n=206)$, being more frequent among women (53.9\%), as shown in Table 1. In this first analysis, the variables that showed to be statistically significant with the occurrence of the outcome were gender, marital status, education, and income.

When evaluating self-reported leisure activities by the elderly, associative activities predominated in both genders, followed by physical activities (Table 2). Still, $36.1 \%$ of the total of elderly reported having leisure activities three times a week or more; and $56.6 \%$ reported the duration of these activities being longer than two hours.
Table 1 - Bivariate analysis of the sociodemographic and economic characteristics of the elderly in the rural area according to leisure activities, Prudentópolis, Paraná, Brazil, 2016

\begin{tabular}{|c|c|c|c|c|c|c|}
\hline & Leis & sure Activ & rities & & & \\
\hline & $\begin{array}{c}\text { Yes } \\
(n=206) \\
n(\%)\end{array}$ & $\begin{array}{c}\text { No } \\
(n=52) \\
n(\%)\end{array}$ & $\begin{array}{l}\text { Total } \\
\text { n (\%) }\end{array}$ & $\begin{array}{c}\text { OR } \\
\text { gross }\end{array}$ & $95 \% \mathrm{Cl}$ & $\begin{array}{c}p \\
\text { value }\end{array}$ \\
\hline Gender & & & & 0.48 & $0.26-0.89$ & 0.015 \\
\hline Female & $139(53.9)$ & $26(10.1)$ & $165(63.9)$ & & & \\
\hline Male & $67(26)$ & $26(10.1)$ & $93(3$ & & & \\
\hline Age & & & & 0.92 & $0.50-1.70$ & 0.460 \\
\hline$\leq 70$ years old & $111(43)$ & $27(10.5)$ & $138(53.5)$ & & & \\
\hline$>70$ years old & $95(36.8)$ & $25(9.7)$ & 120 & & & \\
\hline Marital status & & & & 3.52 & $1.86-6.65$ & 0.000 \\
\hline Partner & $138(53.5)$ & $19(7.4)$ & $157(60.9)$ & & & \\
\hline No partner & $68(26.4)$ & $33(12.8)$ & $101(39.1)$ & & & \\
\hline Education & & & & 2.64 & $1.16-5.97$ & 0.020 \\
\hline up to 4 years of study & $19(7.4)$ & $11(4.3)$ & $30(11.6)$ & & & \\
\hline$\geq 4$ years of study & $187(72.5)$ & $41(15.9)$ & $228(88.4)$ & & & \\
\hline Income & & & & 0.45 & $0.24-0.84$ & 0.010 \\
\hline$\leq 2$ minimum wages & $145(56.2)$ & $27(10.5)$ & $172(66.7)$ & & & \\
\hline$>2$ minimum wages & $61(23.6)$ & $25(9.7)$ & $86(33.3)$ & & & \\
\hline
\end{tabular}

Table 2 - Self-reported leisure activities by elderly living in rural areas according to the type of activity, frequency, and duration, according to genders, Prudentópolis, Paraná, Brazil, 2016

\begin{tabular}{|c|c|c|c|c|c|c|c|}
\hline \multirow[t]{2}{*}{ Leisure Activities } & \multicolumn{2}{|c|}{$\begin{array}{c}\text { Male } \\
(n=67)\end{array}$} & \multicolumn{2}{|c|}{$\begin{array}{c}\text { Female } \\
(n=139)\end{array}$} & \multicolumn{2}{|c|}{$\begin{array}{c}\text { Total } \\
(n=206)\end{array}$} & \multirow{2}{*}{$\begin{array}{c}p \\
\text { value }\end{array}$} \\
\hline & $\mathbf{F}$ & $\%$ & $\mathbf{F}$ & $\%$ & $\mathbf{F}$ & $\%$ & \\
\hline Activities & & & & & & & 0.014 \\
\hline Physical & 21 & 31.3 & $82^{*}$ & 58.1 & 103 & 46.2 & \\
\hline Crafts / Arts & 20 & 29.8 & 27 & 19.2 & 47 & 21.1 & \\
\hline Intellectual & 6 & 8.9 & 12 & 8.5 & 17 & 7.6 & \\
\hline Associative & $64^{+}$ & 95.5 & 97 & 68.8 & 161 & 72.2 & \\
\hline Tourism & 6 & 7.3 & 22 & 15.6 & 28 & 12.6 & \\
\hline Frequency & & & & & & & 0.142 \\
\hline Once a week & 31 & 33.4 & 57 & 34.5 & 88 & 34.1 & \\
\hline Twice a week & 26 & 27.9 & 51 & 31.0 & 77 & 29.8 & \\
\hline 3 times a week or more & 36 & 38.7 & 57 & 34.5 & 93 & 36.1 & \\
\hline Duration & & & & & & & 0.599 \\
\hline up to 1 hour & 9 & 9.7 & 12 & 7.3 & 21 & 8.1 & \\
\hline 1 to 2 hours & 28 & 30.1 & 63 & 38.2 & 91 & 35.3 & \\
\hline$\geq 2$ hours & 56 & 60.2 & 90 & 54.5 & 146 & 56.6 & \\
\hline
\end{tabular}

Table 3 - Multiple logistic regression of factors associated with leisure activities of elderly in rural areas, Prudentópolis, Paraná, Brazil, 2016

\begin{tabular}{lccccc}
\hline Variables & $\begin{array}{l}\text { Model 0 } \\
\mathbf{O R}_{\text {adjusted }}\end{array}$ & $\begin{array}{l}\text { Model 1 } \\
\mathbf{O R}_{\text {adjusted }}\end{array}$ & $\begin{array}{l}\text { Model 2 } \\
\mathbf{O R}_{\text {adjusted }}\end{array}$ & $\begin{array}{l}\text { Model 3 } \\
\mathbf{O R}_{\text {adjusted }}\end{array}$ & $\begin{array}{l}\text { Model 4 } \\
\mathbf{O R}_{\text {adjusted }}\end{array}$ \\
\hline & $\begin{array}{c}3.962 \\
\mathbf{p ~ 0 . 0 0 0}\end{array}$ & & & & \\
Marital status & & 0.28 & 0.31 & 0.34 & 0.37 \\
& & $\mathbf{p ~} \mathbf{0 . 0 0 0}$ & $\mathrm{p} 0.002$ & $\mathrm{p} 0.004$ & $\mathrm{p} 0.007$ \\
Income & & 1.30 & 0.34 & 1.59 \\
& & $\mathrm{p} 0.457$ & $\mathrm{p} 0.301$ & $\mathrm{p} 0.211$ \\
Gender & & & 2.06 & 1.94 \\
& & & & $\mathrm{p} 0.028$ & $\mathrm{p} 0.047$ \\
Education & & & & & 0.42 \\
& & & & & $\mathrm{p} 0.049$ \\
\hline
\end{tabular}
income and marital status. Model 3: adjusted for gender, income, and marital status. Model 4: final model: adjusted for all previous variables. 
Table 3 contains the final analysis of multiple logistic regression. The variables that were statistically associated with the final adjusted model according to leisure activity were: marital status, gender, and education.

\section{DISCUSSION}

The findings produced in this investigation pointed to a high prevalence of leisure activities among elderly living in the studied rural area. Despite the assumption highlighted in the introduction, that access to leisure could be one of the vulnerabilities of this population, another research refutes this statement ${ }^{(15)}$, corroborating our results. Such finding may come from the potential of the state that conducted both surveys (PR), since other studies in different federal units in the country found high results in leisure inactivity, as in the case of Minas Gerais and Amazonas, with $85.5 \%$ and $89.2 \%$, respectively ${ }^{(16-17)}$.

Leisure activity was almost twice as likely to occur among women when compared to men - a result that does not differ when changing the study area. A study conducted in Rio de Janeiro has already demonstrated female superiority in the activities mentioned above, with a prevalence of $58.6 \%$ versus $42.4 \%$ of men $^{(18)}$.

What seems reasonable to consider is that higher mortality rates of men at a younger age ${ }^{(19)}$ could allow, in old age, the composition of the male age group to be more unfavorable than the female group, since, in the rural adult population, women are $6 \%$ to $7 \%$ less active than men in leisure activities ${ }^{(20)}$.

In this sense, marital status is related to the habit of practicing leisure activities. A study conducted in northeastern Brazil confirms our results by showing the presence of the partner as an incentive factor to activities ${ }^{(21)}$, which possibly results from the support and company provided, assisting in the achievement of positive life changes ${ }^{(22)}$. Furthermore, the loss of a partner seems to have a negative impact on the daily lives of this population ${ }^{(23)}$, which may result in isolation and less concern for health, with possible negative influence on their functional capacity ${ }^{(24)}$.

Education was a predictor for the practice of leisure activities in our study. A study conducted in all Brazilian regions identified that the prevalence of leisure-time assets was higher in those with a higher level of education ${ }^{(25)}$. We emphasized that formal education at the beginning of life is an essential marker for cognitive reserve, relating to a lower risk of brain pathologies in aging ${ }^{(26)}$. A study conducted with elderly residents in urban and rural areas of Sri Lanka demonstrated the association of leisure activities with higher levels of cognitive function ${ }^{(27)}$.

Regarding the self-reported activities of the elderly in the rural environment, in this study, it was possible to observe that group leisure activities were the most prestigious among the people investigated. Another study found a similar result ${ }^{(28)}$. Conviviality and social interaction are essential factors in the search for quality of life among the elderly; and, among their motivations, are the improvement in health conditions and the escape from loneliness ${ }^{(29)}$. Research conducted in New Zealand demonstrated that maintaining a social network has a direct impact on the resilience of elderly living in rural areas since many of them do not live near other family members ${ }^{(30)}$.
We highlight that the less sedentary activities were practiced in these rural communities with at least two hours of duration, a value considered good for health promotion. The time of 150 minutes per week of physical activities during leisure time classifies the individual as physically active ${ }^{(31)}$.

There is a tendency for government actions, when they exist, to favor the construction of public spaces in central locations in the city, reinforcing the concept of leisure for only a portion of the population ${ }^{(32)}$. However, in rural areas, one can seek strategic spaces with green areas that allow the development of leisure activities, with the help of a professional when necessary ${ }^{(16)}$, not restricting this population to their place of residence.

Enrolling in leisure activities and the way of spending free time can bring benefits to the elderly so that they can develop their potentials and increase their well-being. In general, positive attitudes tend to be related to higher enrollment in leisure activities, in addition to the experiences that result from it ${ }^{(33)}$.

It is noteworthy that the physical effort resulting from the activities of the countryside and households, experienced by the rural elderly population, are not constituted as a practice of physical activity and are not related to leisure activities ${ }^{(16)}$.

\section{Study Limitations}

The study presents as limitations the place of recruitment of the subjects since individuals who frequently access health services are involved with better life habits, such as, in this case, participation in leisure activities. Furthermore, the fact that most publications refer to leisure physical activities and with populations of large urban centers, the comparisons between studies are limited.

\section{Contributions to the nursing field and public health}

The health of the rural elderly population and aging are relevant issues for public health since the associated comorbidities cause greater need to use health services, which may present particular challenges for this population. As leisure is in the context of health promotion, it should be encouraged and promoted to prevent future cognitive and functional complications. Nurses, as leaders and health promoters, can provide professional support, as well as request help for multidisciplinary teams in order to improve health conditions focusing on an active lifestyle and different realities and contexts of life of the elderly in rural settings.

\section{CONCLUSION}

Concerning the leisure of the elderly, it was possible to identify how these individuals express leisure activities and experiences in the rural setting of Prudentópolis-PR.

We observed that the prevalence of elderly who participated in leisure activities was high, demonstrating that the elderly in the rural area of the studied scenario were frequently involved with leisure activities. The factors associated with the practice were: marital status, gender, and education.

Considering that the practice of leisure activities promotes better living and health conditions, we reinforce the need to implement actions and instruments that provide individual and collective leisure in rural areas. 


\section{REFERENCES}

1. Ralston M. The role of older persons' environment in aging well: quality of life, illness, and community context in South Africa. Gerontologist. 2018;58(1):111-20. doi: 10.1093/geront/gnx091

2. Wedgeworth M, LaRocca MA, Chaplin WF, Scogin F. The role of interpersonal sensitivity, social support, and quality of life in rural older adults. Geriatr Nurs. 2017;38(1):22-6. doi: 10.1016/j.gerinurse.2016.07.001

3. Martins JB, Lange C, Lemões MAM, Llano PMP, Santos F, Avila JA. Avaliação do desempenho cognitivo em idosos residentes em zona rural. Cogitare Enferm. 2016;21(3):01-09. doi: 10.5380/ce.v21i3.48943

4. Ministério da Saúde (BR). Conselho Nacional de Saúde. Lei n 8.080, de 19 de setembro de 1990. Dispõe sobre as condições para a promoção, proteção e recuperação da saúde, a organização e o funcionamento dos serviços correspondentes e dá outras providências [Internet]. Diário Oficial da União: República Federativa do Brasil; 1990 [cited 2019 Apr 29]. Available from: http://www.planalto.gov.br/ccivil_03/leis//8080.htm

5. Kuykendall L, Tay L, Ng V. Leisure engagement and subjective well-being: a meta-analysis. Psychol Bull. 2015;141(2):364-403. doi 10.1037/a0038508

6. Dumazedier J. Sociologia empírica do lazer. São Paulo: SESC; 2012.

7. Van Nguyen T, Van Nguyen H, Duc Nguyen T, Van Nguyen T, The Nguyen T. Difference in quality of life and associated factors among the elderly in rural Vietnam. J Prev Med Hyg. 2017;58(1):E63-E71. doi: 10.15167/2421-4248/jpmh2017.58.1.655

8. Heo J, Kim J, Kim BG, Heo S. Weekend experiences and subjective well-being of retired older adults. Am J of Health Behav. 2014;38(4):598604. doi:10.5993/ajhb.38.4.13

9. Freire T, Fonte C. Escala de atitudes face ao lazer em adolescentes e jovens adultos. Paidéia. 2007;17(36):79-87. doi: 10.1590/ S0103-863X2007000100008

10. Nunes MFO, Hutz CS. Análise da produção de artigos científicos sobre o lazer: uma revisão. Psicol: Teor Pesqui [Internet]. 2014 [cited 2018 Dec 5];30(3):307-15. Available from: http://www.scielo.br/pdf/ptp/v30n3/08.pdf

11. Instituto Brasileiro de Geografia e Estatística (IBGE). Síntese de indicadores sociais: uma análise das condições de vida da população brasileira[Internet]. Brasília: IBGE; 2016[cited 2019 Apr 28]. Available from: https://biblioteca.ibge.gov.br/visualizacao/livros/liv98965.pdf

12. Instituto Paranaense de Desenvolvimento Econômico e Social (Ipardes). Paraná: Ipardes; 2017 [cited 2017 Oct 10]. Available from: www. ipardes.gov.br

13. Ministério da Saúde (BR). Lei no 10.741, de $1^{\circ}$ de outubro de 2003. Dispõe sobre o Estatuto do Idoso e dá outras providências [Internet]. Diário Oficial da União: República Federativa do Brasil; 2003 [cited 2019 Apr 29]. Available from: http://bvsms.saude.gov.br/bvs/publicacoes/ estatuto_idoso_3edicao.pdf

14. Folstein M, Folstein S, McHugh P. "Mini-mental state": a practical method for grading the cognitive state of patients for the clinician. J Psychiatr Res. 1975;12(3):189-98. doi: 10.1016/0022-3956(75)90026-6

15. Ribeiro CG, Ferretti F, Antônio de Sá C. Quality of life based on level of physical activity among elderly residents of urban and rural areas. Rev Bras Geriatr Gerontol. 2017;20(3):330-39. doi: 10.1590/1981-22562017020.160110

16. Pegorari MS, Dias FA, Santos NMF, Tavares DMS. Practice of physical activity among older of leisure in rural area: health conditions and quality of life. Rev Educ Fís. 2015;26(2):233-41. doi: 10.4025/reveducfis.v26i2.25265

17. Rêgo AS, de Oliveira BLCA, Silva AM, Chagas DC, Rodrigues MAFRA, de Brito e Alves MTSS, Thomaz EBAF. Frequency and factors associated with leisure physical activity among adults in Brazil and in the Amazon: population-based study. Rev Pesq Saúde [Internet]. 2016 [cited 2019 Dec 26];17(3):159-65. Available from: http://www.periodicoseletronicos.ufma.br/index.php/revistahuufma/article/viewFile/6789/4331

18. Rodrigues P, Bustamante CG, Reis EC, Palma A. Practice of physical activity in leisure and socioeconomic conditions in the city of Rio de Janeiro. Rev Saúde Física Mental [Internet]. 2017 [cited 2019 Dec 26];5(2):1-13. Available from: https://revista.uniabeu.edu.br/index.php/ SFM/article/view/3080/2071

19. Bidinotto DNPB, Simonetti JP, Bocchi SCM. Men's health: non-communicable chronic diseases and social vulnerability. Rev Latino-Am Enfermagem. 2016;24(e2756):1-8. doi: 10.1590/1518-8345.0735.2756

20. Biernat E, Bartkiewicz P, Buchholtz S. Are structural changes in Polish Rural areas fostering leisure-time physical activity? Int J Environ Res Public Health. 2017;14(4):1-15. doi: 10.3390/ijerph14040372

21. Rodrigues WKM, Rocha SV, Vasconcelos LRC, Diniz KO. Physical activity level and functional disability among elderly in the rural area of a municipality in northeastern Brazil. Rev Bras Promoç Saúde [Internet]. 2015 [cited 2019 Apr 28];28(1):126-32. Available from: https:// periodicos.unifor.br/RBPS/article/view/3110/pdf

22. Oliveira DV, Silva TPS, Scherer FC, Nascimento Júnior JRA, Antunes MD. O tipo de exercício físico interfere na frequência da prática de atividade física, comportamento sedentário, composição corporal e estado nutricional do idoso? Rev Bras Nutr Esportiva [Internet]. 2019 [cited 2019 Apr 28];13(77):3-16. Available from: http://www.rbne.com.br/index.php/rbne/article/view/1211/853

23. Nunes JD, Saes MO, Nunes BP, Siqueira FCV, Soares DC, Fassa MEG, et al. Functional disability indicators and associated factors in the elderly: a population-based study in Bagé, Rio Grande do Sul, Brazil. Epidemiol Serv Saúde. 2017;26(2): 295-304. doi: 10.5123/ S1679-49742017000200007 
24. Farías-Antúnez S, Lima NP, Bierhals IO, Gomes AP, Vieira LS, Tomasi E. Disability relating to basic and instrumental activities of daily living: a population-based study with elderly in Pelotas, Rio Grande do Sul, Brazil. Epidemiol Serv Saúde. 2018;27(2):e2017290. doi: 10.5123/ S1679-49742018000200005

25. Mielke GI, Malta DC, De Sá GBAR, Reis RS, Hallal PC. Regional differences and correlates of leisure time physical activity in Brazil: results from the Brazilian National Health Survey-2013. Rev Bras Epidemiol. 2015;18(2):158-69. doi: 10.1590/1980-5497201500060014

26. Groot C, Hooghiemstra AM, Raijmakers PG, Van Berckel BN, Scheltens P, Scherder EJ, et al. The effect of physical activity on cognitive function in patients with dementia: a meta-analysis of randomized control trials. Ageing Res Rev. 2016;25:13-23. doi:10.1016/j. arr.2015.11.005

27. Maselko J, Sebranek M, Mun MH, Perera B, Ahs J, Ostbye T. The Contribution of Generative Leisure Activities to Cognitive Function among Sri Lankan Elderly. J Am Geriatr Soc. 2014;62(9):1707-13. doi: 10.1111/jgs.12985

28. Castro VC, Carreira L. Leisure activities and attitude of institutionalized elderly people: a basis for nursing practice. 2015;23(2):307-14. doi: 10.1590/0104-1169.3650.2556

29. Ferreira MCG, Tura LFR, Silva RC, Ferreira MA. Social representations of older adults regarding quality of life. Rev Bras Enferm. 2017;70(4):80613. doi: 10.1590/0034-7167-2017-0097

30. Neville S, Adams J, Napier S, Shannon K, Jackson D. Engaging in my rural community": perceptions of people aged 85 years and over. Int J Qual Stud Health Well-being. 2018;13(1):1503908. doi: 10.1080/17482631.2018.1503908

31. Madeira SG, Sousa PA, Envia G, Marques S, Moreira TM. Physical activity counseling: a proposed clinical intervention flowchart. Acta Médica Portuguesa. 2018;31(6):295-98. doi: 10.20344/amp.9920

32. Florindo AA, Barrozo LV, Cabral-Miranda W, Rodrigues EQ, Turrell G, Goldbaum M, et al. Public Open Spaces and Leisure-Time Walking in Brazilian Adults. Int J Environ Res Public Health. 2017;14(6):553. doi:10.3390/ijerph14060553

33. Choi S, Yoo Y. Leisure attitude and satisfaction with leisure and life: proposing leisure prioritization and justification, World Leisure J. 2016;59(2):1-15. doi:10.1080/16078055.2016.1216886 